\title{
(In)dependent meaning: Representations of addiction and recovery in selected poems produced in a rehabilitation centre
}

\begin{tabular}{|c|c|}
\hline \multicolumn{2}{|c|}{$\begin{array}{l}\text { Authors: } \\
\text { Antoinette Pretorius }{ }^{1} \text { (1) } \\
\text { Andy Carolin } \\
\text { Reinhardt Fourie }^{1} \\
\text { Lida Krüger }^{1}\end{array}$} \\
\hline \multicolumn{2}{|c|}{$\begin{array}{l}\text { Affiliations: } \\
{ }^{1} \text { Department of English } \\
\text { Studies, University of South } \\
\text { Africa, South Africa }\end{array}$} \\
\hline \multicolumn{2}{|c|}{$\begin{array}{l}\text { Project research number: } \\
2015 \text { CHS } 018\end{array}$} \\
\hline \multicolumn{2}{|c|}{$\begin{array}{l}\text { Corresponding author: } \\
\text { Reinhardt Fourie, } \\
\text { fourir@unisa.ac.za }\end{array}$} \\
\hline \multicolumn{2}{|c|}{$\begin{array}{l}\text { Dates: } \\
\text { Received: } 31 \text { Jan. } 2017 \\
\text { Accepted: } 15 \text { June } 2017 \\
\text { Published: } 31 \text { Aug. } 2017\end{array}$} \\
\hline \multicolumn{2}{|c|}{$\begin{array}{l}\text { How to cite this article: } \\
\text { Pretorius, A., Carolin, A., } \\
\text { Fourie, R. \& Krüger, L., 2017, } \\
\text { '(In)dependent meaning: } \\
\text { Representations of addiction } \\
\text { and recovery in selected } \\
\text { poems produced in a } \\
\text { rehabilitation centre', Literator } \\
\text { 38(1), a1395. https://doi.org/ } \\
\text { 10.4102/lit.v38i1.1395 }\end{array}$} \\
\hline \multicolumn{2}{|c|}{$\begin{array}{l}\text { Copyright: } \\
\text { (C) 2017. The Authors. } \\
\text { Licensee: AOSIS. This wC } \\
\text { is licensed under the } \\
\text { Creative Commons } \\
\text { Attribution License. }\end{array}$} \\
\hline \multicolumn{2}{|l|}{ Read online: } \\
\hline 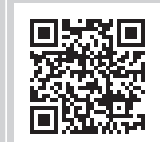 & $\begin{array}{l}\text { Scan this QR } \\
\text { code with your } \\
\text { smart phone or } \\
\text { mobile device } \\
\text { to read online. }\end{array}$ \\
\hline
\end{tabular}

In this article we provide a close reading of selected poems written during creative writing workshops at a drug rehabilitation centre. We argue that these poems expose some of the uncertainties and complexities that characterise the representation of identity in experiences of addiction and recovery. We show that the speakers in these poems attempt to imagine and represent their experiences in language through a number of structuring binaries. These binaries include those between the speaker's experiences of active addiction and recovery, and the speaker's personal experience versus societal expectations and perceptions. Our reading of these poems is informed by the clinical context in which they were written, and our analysis reflects the bifurcation that governs this liminal space. Individual agency in these different spheres is approached in a very tentative way, and the speakers in these poems are shown to have trouble envisioning the future at the same time as their pasts appear unsettled. We argue finally that while current discourses and vocabularies surrounding addiction seem incomplete and inadequate for the expression of some complex experiences, poetry provides a platform that accommodates ambivalence and a multiplicity of meanings.

(On)afhanklinke betekenis: Voorstellings van verslawing en herstel in geselekteerde gedigte geskryf in 'n rehabilitasiesentrum. Hierdie artikel ondersoek 'n aantal geselekteerde gedigte wat geskryf is tydens kreatiewe skryfwerkswinkels aangebied by 'n dwelmrehabilitasiekliniek. Ons voer aan dat hierdie gedigte sommige onsekerhede en kompleksiteite blootlê wat die representasie van identiteit in ervarings van verslawing en herstel kenmerk. Ons toon aan dat die sprekers in hierdie gedigte probeer het om hulle ervarings deur ' $n$ aantal binêre teenstellings in taal te versinnebeeld. Dít sluit in die teenstelling tussen die spreker se ervaring van aktiewe verslawing en herstel, en die spreker se persoonlike ervaring teenoor maatskaplike verwagtinge en persepsies. Ons interpretasies van hierdie gedigte word gerig deur die kliniese konteks waarbinne hulle geskep is, terwyl ons ontleding die splitsing weerspieël wat hierdie liminale ruimte oorheers. Individuele agentskap binne hierdie verskillende gebiede word op tentatiewe wyse benader, en daar word aangedui hoe die sprekers in hierdie gedigte met moeite ' $n$ toekoms insien terwyl hul verledes terselfdertyd rusteloos voorkom. Uiteindelik argumenteer ons dat terwyl teenswoordige diskoerse en uitdrukkingsmoontlikhede betreffende verslawing onvolledig en onvoldoende blyk te wees vir die uiting van veelvuldige ervarings, bied juis die poësie ' $n$ platform wat teenstrydighede en menigvuldige betekenisse kan akkommodeer.

\section{Introduction}

Nothing is more punitive than to give a disease a meaning - that meaning being invariably a moralistic one. Any important disease whose causality is murky, and for which treatment is ineffectual, tends to be awash in significance. At first, the subjects of deepest dread (corruption, decadence, pollution, anomie, weakness) are identified with the disease. The disease itself becomes a metaphor. Then, in the name of the disease (that is, using it as metaphor), that horror is imposed on other things. The disease becomes adjectival. (Sontag 1978:58)

Though Susan Sontag's disquisitions on the cultural construction of disease in Illness as Metaphor (1978) and later AIDS and Its Metaphors (1989) unravel the prevailing figurative dimensions of physiological medical conditions, the arguments made by Sontag in these books find resonance with the phenomenon of addiction in its broader sense. As a 'disease' and social phenomenon, addiction has become thoroughly metaphorised. Addictions, such as cancer, tuberculosis and 
AIDS, is imbued with cultural significance and exists at the locus of various competing ideologies that inform and undermine the normative centre from which the addict has deviated.

Situated from within a literary studies perspective, this article reads the textual inscription of addiction as a discursive formation of identity. This construction is underscored by a complex interplay of authorial context, narrative voice, societal preconception and what we might call poststructuralist reading practices. The purpose of this article is neither to promote the validity of one particular view on addiction, nor to study the extent to which each view may or may not influence the ways in which an individual addict constructs a sense of self. Rather, through a subjective analysis of poems emanating from creative writing workshops presented at a rehabilitation centre, we argue that poetry, preoccupied as it is with the play of ambiguity and metaphor, acts as a mode of expression especially suited to expressing the contradictions posed by these discourses. We suggest, in particular, that the technique of cut-and-paste poetry employed in a workshop context allows for a critical engagement with how the textual representation of addiction seems to hinge on a sense of identity which is always contingent and constructed.

\section{Discourses surrounding addiction and agency}

While the spectre of morality continues to hold sway over public perceptions of addiction, research into its causes encompasses an array of seemingly contradictory discourses that often highlight the interrelation of medical, psychological and sociocultural factors. While all of these models work towards an envisioned future in which the individual addict overcomes his or her addiction through regaining agency, the degree of power accorded to an addictive identity formation varies. As with the signification of physiological conditions that Sontag discusses above, addiction is accorded the 'subjects of deepest dread', its sufferers function symbolically as extreme embodiments of the 'corruption, decadence, pollution, anomie, weakness' that always threaten to encroach upon the healthy body of society (Sontag 1978:58). The addict, the mirror image that hypostasises and refracts society's moral burden, is tasked with the normalisation of excess, the regulation of appetite. This process of refraction, of creating distance between the healthy subject and the diseased other, frames addiction as a discursive structure to ensure that its reach never extends to the normative centre.

Rationalising the ostensibly irrational behaviour of the addict, the medical view of addiction subordinates personal agency to pharmacological, pathological, neurological or evolutionary concerns (Coonfield 2008:93; Morgenstern \& McCrady 1992; Wiens \& Walker 2014). The aberrant body becomes an object to be scrutinised and then corrected through a regime that usually involves detoxification and therapeutic treatment. While the medical view tends to limit personal agency on the basis of neuroscience, some psychological constructions of addiction do so through their suggestion that a lack of willpower controls the addict's behaviour: the addict may desire to change but lacks the strength to do so (May 2001). Behavioural strategies linked to the psychological model such as 'delay tactics, using imagery to weaken cravings, visualising negative consequences and substituting activities for the addictive behaviour' (Clark 2011:60) are some of the recommended methods of treatment. In contrast to these conceptions of addiction, the moral view grants the addict full agency (Foddy \& Savulescu 2010) and as such confers on him or her full moral culpability:

A strong moral opprobrium exists against the seeking of deleterious pleasures. Health, as popular morality would have it, is worth more than a good time, and whenever a person makes the reverse valuation, it is assumed that they are disordered, reckless, or wanton. (p. 7)

The addict, in this view, is accused of prioritising pleasure over his or her well-being.

And yet, as Lucy Bailey (2005:593) points out, 'in contemporary discourses, consumption is used as a source perhaps the source - of identity, and addiction stands as the logical extreme of such a consumption identity'. When excess and indulgence - the very principles of capitalism - find one of their most potent crystallisations in addictive behaviours, society, morally alert, withdraws, diagnoses, and vilifies, offering an ethical bifurcation: there are 'good' drives, it is implied (financial success, power, the acquisition of an everexpanding collection of things), and there are 'bad' drives (indulging in drugs, engaging in meaningless sexual activity or heedless self-destructive pleasure). In other words, the medical, psychological and moral conceptual models of addiction appear to agree on two things: firstly, not only are the acceptable drives not indulgences but they are in fact prerequisites for fulfilment. Secondly, although the reprehensible drives satisfy a need for the addict, they ultimately do not fulfil but empty out.

While the discourse that locates the origin of addiction in biological causes has become fairly ubiquitous, it continues to be disregarded in favour of popular understandings of addiction that foreground personal culpability and moral defect. The addict, for example, is a lung cancer patient who smokes a box of cigarettes a day, is censured for a corrupt lifestyle, a moral failing and a spiritual weakness. Like cancer, addiction has ramified; acquiring adjectives, its reach stretching beyond a dependence on substances such as alcohol or drugs, or practices such as compulsive sexual behaviour. This implies that one can be addicted to a variety of 'unhealthy' behaviours such as over-eating, gambling or the obsessive consumption of pornography. It is the causes of these excessive compulsions that are subsumed by the addiction-as-disease model. Colloquial language also allows for apparent addictions to reading, to coffee, to favourite television programmes, to any number of lifestyle preferences that fall outside the direct production of labour. Significantly, also individualised labour - in its colloquial sense - can be seen as an addiction when it distracts a person from even more supposedly wholesome pursuits such as parenting, as 
in the case of the so-called 'workaholic'. These guilty pleasures are not understood as having biological causes and become a form of permissible hedonism - a vice sanctioned by the same capitalist dispensation that by its very nature as a culture and economy of consumption, is centred on the satisfaction of material desires. This tenuously balanced individualisation is embedded in a particular free-market discourse of self-regulation that extends from the economic condition to the individual, simultaneously encouraging unfettered consumption and imposing normativities of excess. The person who claims to be addicted to reading, for example, rarely means that the normal functioning of his or her life is detrimentally affected by the time he or she spends reading. Flirting with the transgression associated with addiction proper, this kind of claim to addiction aims to curate the commercially and socially acceptable projection of identity to which true addicts have no access - the coffee lover flaunts his or her dependency as a consumerist badge of distinction, a proud declaration that he or she is the type of person in thrall to coffee, in a way the heroin user never could.

Addictive identity formation, then, centres on a position of irreconcilable irony where agency is meted out and retracted in line with fluctuating societal discourses that regulate the condition. These discourses converge most potently in the rehabilitative context. Rehabilitation centres are by no means homogenous in their attitude towards or treatment of addiction (some aim to rehabilitate through hard-line deprivation intended to shock the addict into an awareness of his or her transgression while others favour a gentler holistic approach that foregrounds talk and behavioural therapy). However, the performances of addiction and recovery are located in a discernible therapeutic rhetoric: the addict retreats from society to an insular environment where he or she is guided in the rebuilding of a conception of a life devoid of the habitudes of addiction. Part of this process involves a negotiation and internalisation of a combination of the contrasting discourses discussed above. As our analysis of the poems in the following section suggests, this overwhelmingly results in the construction of an identity underpinned by ambiguity and bifurcation. It is of course not our suggestion that structured rehabilitation practices are unnecessary or ineffective. On the contrary, we acknowledge the incredible importance of different therapeutic responses to addiction and the different forms of support that are provided for recovery. It is our contention, rather, that creative writing exposes some of the epistemological challenges or blind spots faced in therapeutic practice and that poetry might engage productively with what are already important rehabilitative programmes.

\section{Text and context}

The poems that are considered below form part of the creative output from poetry writing workshops that took place at an in-patient rehabilitation centre in Gauteng, South Africa. Rather than forming part of the integrated therapeutic practices of the centre, these workshops focused on how the generic elements of poetry might be used productively to think differently about language, identity and narrative perspective. Writing in the Journal of Poetry Therapy, Jan L. Hitchcock (2005:195) and Wanda Springer (2006:72) note that it is the form and function of poetry - particularly the multiplicities of meaning and ambivalence, respectively - that make it so effective in understanding and working with liminal and vulnerable groups such as recovering addicts. While there has been an increase in research on using poetry as an explicitly therapeutic tool to treat addiction (Randolph 2012; Springer 2006), this article is a definitively literary study of the themes that emerged in a selection of poems. The 7-week programme was facilitated by two of the researchers and focused on the central characteristics and techniques of poetry as a genre. Participants were encouraged to write several poems over this period. The activities took the form of 'free writing' in which, according to Anton Krueger (2015:103), ' $t$ t] ime imagination is given a springboard into the unknown, and having permission to play, experiment (and fail) can help students evade blockages which come from trying too hard'. In these instances, the participants were given writing guidelines that were linked to specific techniques such as alliteration, rhyme, intertextuality, syllabic form, and syntax. ${ }^{1}$ Given that impersonal and broadly conceptualised thematic ideas tend to occlude more complex feelings and experiences in many introductory creative writing programmes (Dladla 2015:89), the participants were not bound to particular topics. Instead, suggestive words such as 'yesterday', 'today' or 'tomorrow' functioned as the creative springboards to which Krueger refers. The four poems below were produced in the final two workshop sessions in which the participants were given popular magazines and asked to identify words that resonated with them, in whichever way, and to cut them out. The participants were then invited to construct their own poems on any topic, using only these collected words, allowing what Krueger (2015:105) calls the 'playful forcing of discovery'. As Leti Kleyn argues, using the cut-and-paste method in a creative writing workshop context has several benefits: it works against an elitist approach to literature (2012:7); it undermines the inviolability of printed text (2012:7); and it gives inexperienced poets a body of words from which to work, thereby making the process of writing less daunting (2012:10). Our analysis of these poems further demonstrates that this method is a powerful way of opening up new ways of thinking about the contingent relationship between language, identity and experience. It grants the participants the opportunity to create their own metaphors with which to approach their condition, whether or not these dissent against the seemingly hegemonic metaphors of addiction in the colloquial sense.

Of course, our reading of these poems as literary texts is an inherently subjective process. The clinical context of their production has invariably informed our own emphasis on

1.Most discussions and activities during the workshops focused on topics such as specific poetic techniques. The outcomes of these writing activities included. a collective poem in which participants each contributed a single line, poems inspired by randomly allocated paint-colour cards; poems with a prescribed number of syllables, words, or lines; poems with prescribed alliteration patterns or rhyme schemes; and intertextual poems consisting only of song lyrics, advertising jingles, or lines from films and television. 
themes of addiction and recovery. An analysis less tied to the practices of recovery might very well have identified an alternative set of concerns and discourses. However, context should not be confused with intentionality: while the context in which these poems were written foregrounds in our analysis particular discourses, we do not claim insight into the state of mind of the participants themselves. ${ }^{2}$ We are interested, rather, in how four poems produced in a particular clinical context might shift the way we think about addiction and recovery as discursive practices. We focus, therefore, on the position of the speaker in these poems in order to evaluate how each one rearticulates subjectivities of excess.

\section{A reading of addiction and recovery in the selected poems}

These four poems overwhelmingly demonstrate a sincere (though ultimately impossible) attempt at a clear delineation between experiences of addiction, spaces of recovery and future projections of agency, and were selected for that reason. Experiences of addiction are represented in ostensibly unambiguous terms that serve to distance the speakers from a past that must be elided to allow for the creation of a new sense of self defined by something other than addictive behaviours. This manifests textually in binary distinctions that metaphorically demarcate addiction from recovery. For example, in one poem, the speaker portrays rehabilitation as 'health' and addiction as the fight against the temptation of 'fabulous goodies' ('Time to get summer-ready' 10) such as 'chocolates, burgers and biscuits' ('Time to get summerready' 6). In another, this delineation is coded as the distinction between drowning and surfacing ("The lingering blackness'). Ironically, in our reading, this leads to a fractured subjectivity in which the speakers are trapped in the liminal space of recovery, unable to resort to the past for comfort and powerless to imagine clearly a future beyond the present. Because of this, all of the poems evidence ambiguous slippages in meaning that undermine the construction of a clear distinction between the concepts of 'addiction' and 'recovery'. These poems thus evidence the difficulties involved in finding a language in which to express the position of the self in relation to the ambivalent processes that define the rehabilitative experience. The four poems that are discussed are titled 'Up, up and away!', 'Time to get summer-ready', 'Armageddon chess' and 'The lingering blackness' (also see Figures 1-4).

\section{Up, up and away! $!^{3}$}

Up, up and away!

This is the one time to shine

The spectacular extravaganza is days away 3

No rehab and hopefully good, clean fun $\quad 4$

Unforgettable moments. The times she dominated. 5

2.Whereas psychoanalysis as a literary approach might have been a productive lens for analysing these poems, this is not the intellectual orientation of this article as we for analysing these poems, this is not the intellectual orientation of this article as we recovery than in individualised readings of individual poets.

3.The presentation of the poems has been standardised here for the sake of readability. See the reproductions of the poems themselves for the original text.
This is a girl on fire! Who leaves fear at the door.

Simple functional and beautiful boots fit for a princess

Small luxuries. Happy landings

Excitedly having a blast in superb views and luxury

treehouses which feel like a fairyland

Make a holiday of it!

Lighting my way which is contour intuitive

'By overcoming difficulties I gain strength and maturity'

'I love nothing more than home!'

To live a happy, colourful life

You did it, buddy!

This poem details the speaker's construction and projection of the positive, addiction-free identity that she envisions assuming once she has left the institutionalised space of the rehabilitation centre. In this instance, the rehabilitation context is made explicit in the poem. This sense of identity, however, is undermined throughout the poem by the speaker's inability to imagine precisely the shape this new life will take. Imperatively suggesting the necessity for upward movement, the first line of the poem contains elements that are carried through until its conclusion. While the word 'up' (1.1) ostensibly indicates the heightened superiority of this new self she envisages becoming, it also conveys the distance between where she finds herself and where she wishes to be, suggesting the seeming unattainability of the new identity. The directionality of the use of 'away' (1. 1) reinforces the fact that the future remains unknowable, as it suggests movement from the present, rather than movement towards the future. That ' $[\mathrm{t}] \mathrm{his}$ is the one time to shine' (1. 2) conveys the speaker's awareness that the identity she is to assume will not be an insular one, and that, rather, it will be constructed under the scrutiny of society's gaze, as is implied by the emphasis and specificity suggested by the words 'this' and 'one time' (1. 2). The sense of impending pressure continues into the next line where the speaker states that '[t]he spectacular extravaganza is days away' (1. 3, our emphasis), simultaneously indicating the distance between the present and the future and highlighting the inevitability of the coming change. This can be associated with the liminal subject position that characterises the production of the selected poems more generally.

The speaker's use of the words 'spectacular extravaganza' (1. 3) conveys a degree of hyperbolic performativity that alludes to the difficulty involved in realigning to an identity that conforms to societal mores, a realignment visible as well in 'Armageddon chess'. The triteness of the phrase foregrounds the ways in which the future remains unknowable, suggesting that the speaker lacks the vocabulary with which to articulate, and in doing so map, the contours of the future. This can also be seen in the clichéd use of the term 'good, clean fun' (1. 4) in the next line. The word 'hopefully' (which has been purposefully inserted) qualifies the 'good, clean fun' (1. 4) and gestures towards the fragility of the identity that the speaker is attempting to assume. The cut-and-paste form is revealing here as it typographically delineates the hopefulness as a contingent afterthought. It is significant that this line 


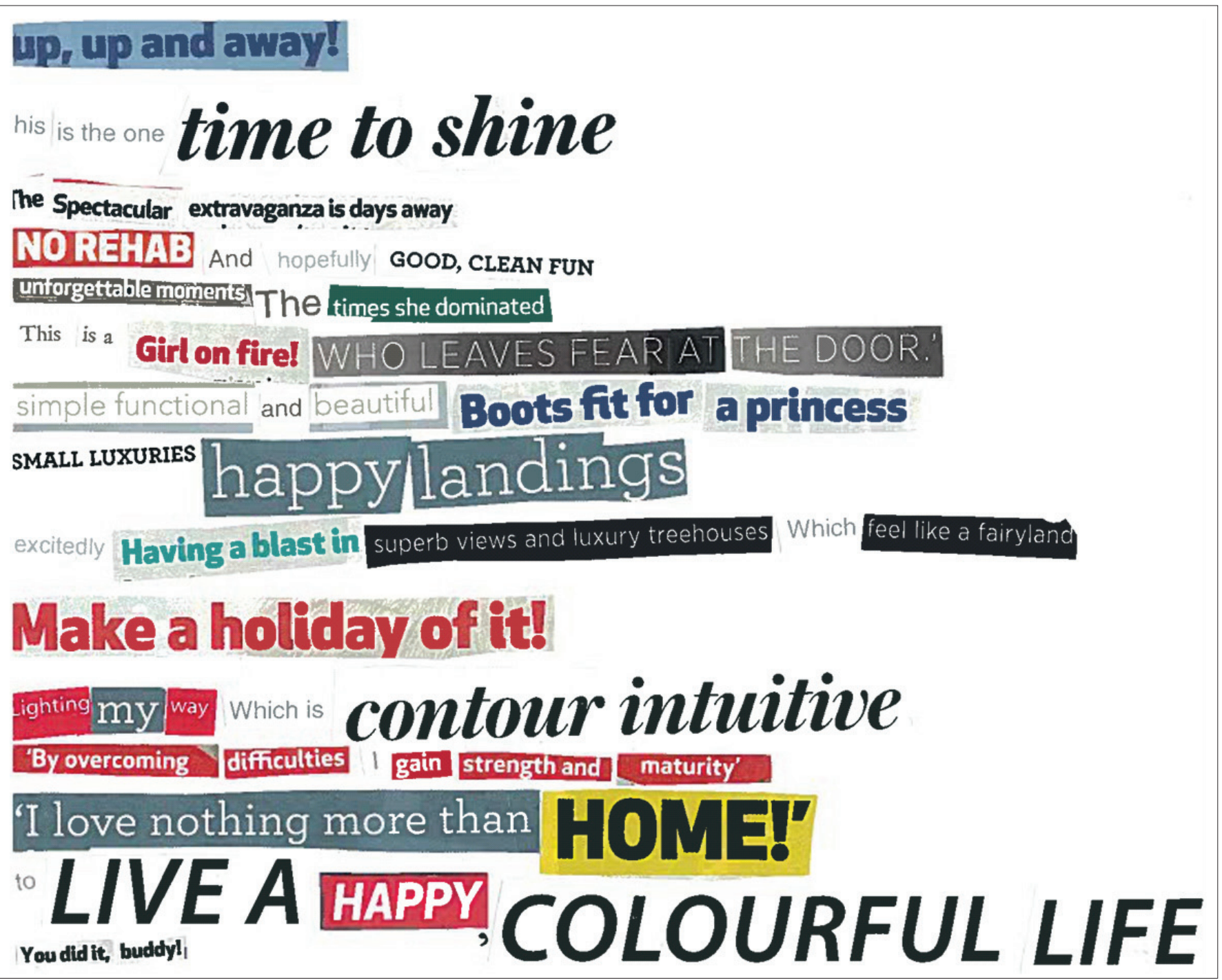

Source: Anonymous (2015d)

FIGURE 1: 'Up, up and away!'.

elides any association with the drug-related behaviour that characterised the 'old' self, and rather posits that the future will be defined by '[n]o rehab' (1. 4), as this connotes the speaker's uncertainty surrounding the construction of a new identity in a space unmoored from the familiar past and rehabilitative present. If the past is to be erased and the future can only be understood in a language to which the speaker has no access, her subjectivity is defined above all by an almost paralysing ambiguity.

This dislocation from the present can also be seen in her statement that '[t]his is a girl on fire!' (1. 6). This description of her identity yet again relies on an external authority for its validation, and in doing so highlights the distance between the separate selves that the speaker represents. The speaker hints at what may be the obstacle preventing the unification of her fractured identity: this 'girl on fire' will need to 'leave [...] fear at the door' (1. 6). The 'door' (1. 6) again suggests that her past, present and future selves are separate entities that require careful delineation in order for her to enact movement through the 'door' (1. 6) towards whatever may await her in the future.
In the next section of the poem, the speaker attempts to describe what the 'girl on fire' will find on the other side of the 'door' (1. 6). The 'girl' (1. 6) has ascended to the status of 'princess' (1. 7) and is dressed in 'beautiful boots' (1. 7). In the face of the uncertain future, these '[s]mall luxuries' (1. 8) function as tangible material evidence of the changed status she envisions. She will have 'a blast' in 'luxury treehouses' with 'superb views' (1. 9). The altitude of this description resonates with the poem's first line as it too suggests the distance between the present and the seemingly unattainable future, while the use of the word 'superb' reflects the earlier hackneyed descriptions of this new life. Here, however, the speaker is able to convey some measure of agency: whereas previously she had been the gazed-upon object, her new identity will afford her the opportunity to assume a subject position as the one who gazes. This sense of projected agency is tenuous, however, as can be seen in her description of her kingdom as a 'fairyland' (1. 9). The fragility of this positive identity can also be seen in her reversion to the previouslyestablished and externally-imposed imperative to '[m]ake a holiday of it' (1. 10) - a 'holiday' (1. 10) signifying a temporary 


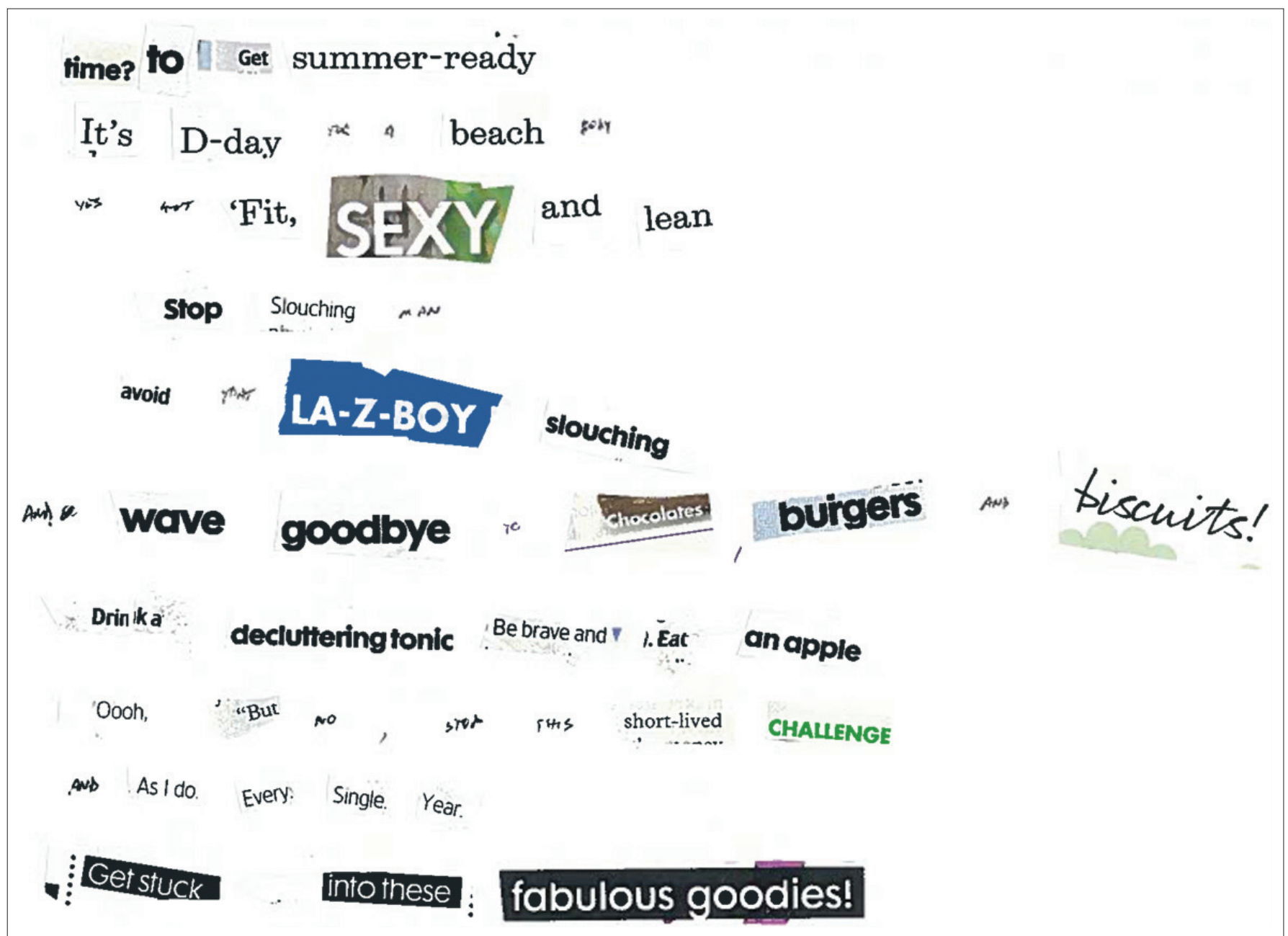

Source: Anonymous (2015c)

FIGURE 2: 'Time to get summer-ready'.

escape from the realities of life rather than a sustainable state of existence.

The next line of the poem evidences the ways in which the cut-and-paste poetic technique may lead to the creation of alternative, unintended meanings. The speaker explains that in this unfamiliar, unexplored terrain, she will have to 'light [...]' her 'way', and that this is 'contour intuitive' (1. 11). We are less interested in whether or not the poet intended to use the word 'contour' (1. 11) rather than the idiomatic 'counter' than in what new meanings this slippage might generate. If the word is read as 'counter', the implication is that the speaker will have to alter established patterns of behaviour in order to find her way forward. The meaning, however, gains layers of nuance when the word is read as 'contour', as this creates the image of a blind explorer having to feel her way through the darkness of this unknowable future, navigating her way by the 'contour[s]' of what she encounters. Almost as if in reaction to the terrifying ambiguity presented by this image, the next two lines consist of quoted aphorisms. Again, the cut-and-paste poetic technique here reveals a multiplicity of meaning to which the reader does not have access in conventionally printed poetry. As Kleyn explains, this technique allows for a critical evaluation of the conventional rules governing the relationship between the writer, the process of writing and the reader (2012:9).

In the line that reads 'By overcoming difficulties I gain strength and maturity', the poet purposefully inserted the word ' $I$ ' from a different printed source. This wilful insertion of subjectivity goes some way towards mitigating the fragile triteness of the line as well as the displacement from selfevoked by the quotation marks. This sense of agency continues into the next line where the speaker states that she 'love[s] nothing more than home $[\ldots]$ '. This is in contrast to the previous sections of the poem in which the speaker's future trajectory was defined by negation ['No rehab' (1. 4)], by the gaze of society ['spectacular extravaganza' (1.3)], and in which it was coded as being as unattainable as a 'fairyland' (1. 9). Now, the speaker begins to articulate and define that which she is moving towards as 'home' (1.13). This articulation, however, remains tentative and uncertain, as the poet chose to retain the quotation marks that displace the speaker from her utterances.

The final line of the poem summarises the ambiguous agency that characterises the position the speaker occupies throughout the poem. Again, it is a projection directed 


\section{Armageddon Chess}

Doubled seven branched light Reflecting flames

these are The standards of The Game

\section{Me Wove worthy and brave}

\begin{tabular}{l|l} 
Other wise & You ought to be ashamed
\end{tabular}

it MIL Make you an angelic saint

Glowing WiTH true skilful and talented master play

. Or

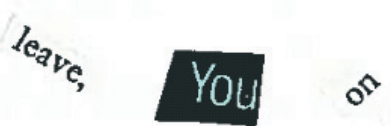

the granite rocks in

the. reflection 0 f

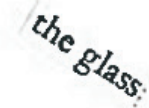

gray

Source: Anonymous (2015a)

FIGURE 3: 'Armageddon chess'.

backwards from an unspecified point in the future towards the speaker's present self: 'You did it, buddy!' (1. 15). While this line signifies pride and success, the speaker still remains unable to visualise herself as inhabiting this accomplishment, as can be seen by the sudden use of the second-person narrative voice. Similarly, 'buddy', (1.15), the term of endearment with which the poem concludes, reintroduces the scrutiny of an imagined external observer and points to the ways in which the speaker's identity is constituted by conflicting discourses and expectations, an ambiguity that is characteristic of the other poems in this study.

\section{Time to get summer-ready}

Time to get summer-ready It's D-day for a beach body
Yes for fit, sexy and lean

Stop slouching man

Avoid that lazy boy slouching

And wave goodbye to chocolates, burgers and biscuits

Drink a decluttering tonic. Be brave and eat an apple

Oooh but no, stop this short-lived challenge

And as I do every single year

Get stuck into these fabulous goodies!

4

5

6

7

8

The poem traces how the speaker's commitment to personal fitness, attractiveness and health is replaced by an admission that he cannot resist the appeal of unhealthy 'fabulous goodies' (1. 10). On the surface, the poem can be read as a statement of self-actualisation in which a series of externallyimposed expectations are disavowed. The speaker is initially reminded of the popular valorisation of being 'fit, sexy and 


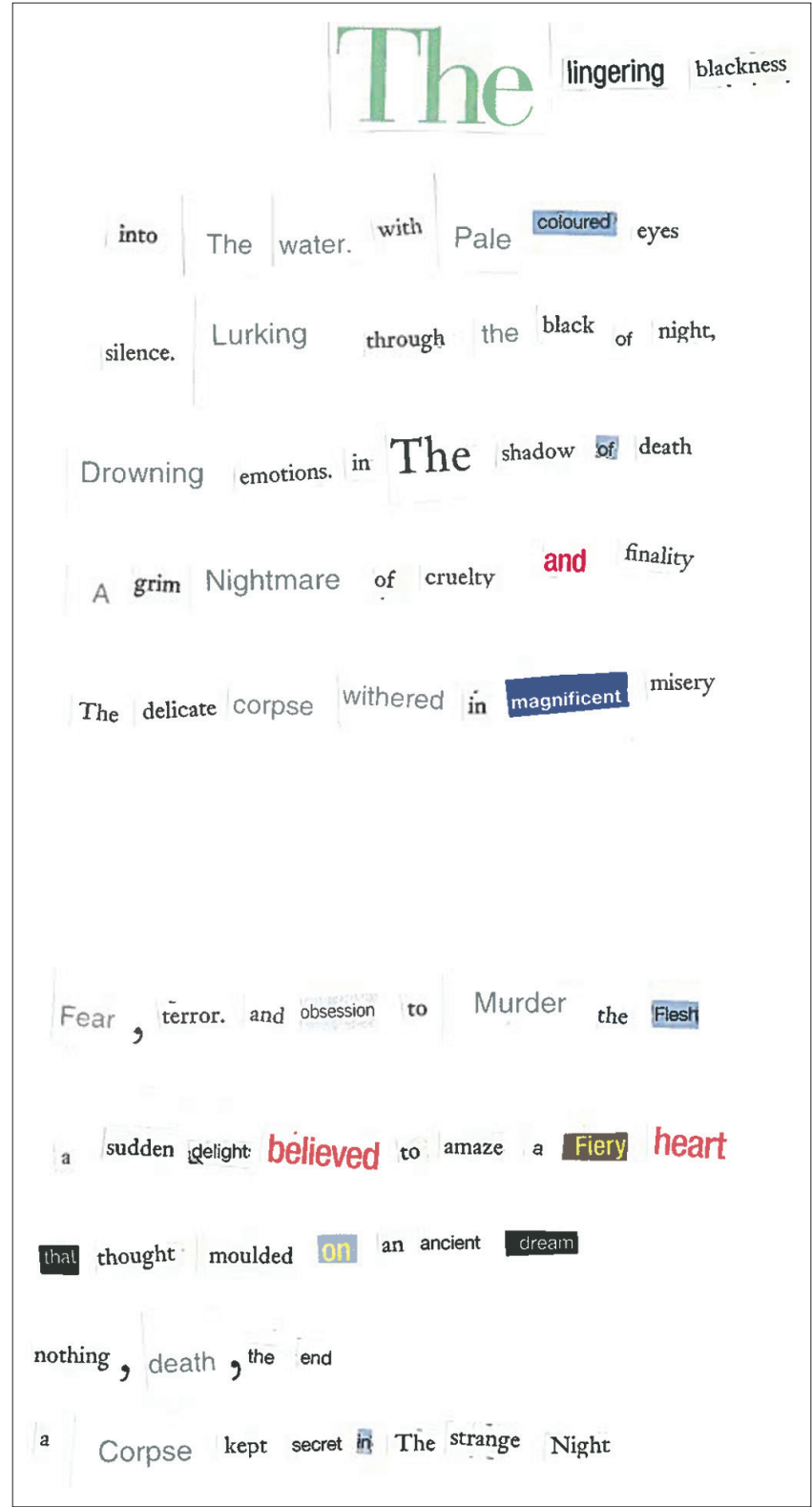

Source: Anonymous (2015b)

FIGURE 4: 'The lingering blackness'.

lean' (1. 3) and recalls an instruction to '[s]top slouching man' (1.4) and 'wave goodbye to chocolates, burgers, and biscuits' (1. 6). The second-person imperative, which contrasts the first-person perspective later in the poem, points to the unassimilated intrusion of society's norms in the constitution of the speaker's sense of self in a manner similar to the shifting narrative perspective in 'Up, up and away!'. The speaker here indicates his refusal to comply with these expectations when he says '[o]ooh but no, stop this shortlived challenge' (1. 8). However, we argue that in this poem the specific experience of addiction is transposed onto the more general ideas about willpower and healthy living, pointing to a desire for a more broadly articulated identification beyond the confines of a rehabilitation centre or addiction recovery models (making the choice of popular magazines as source material particularly apposite). In other words, the speaker's focus on 'get[ting] summer-ready' (1. 1) offers a sustained metaphor for sobriety and recovery while denying the alterity and unknowability within which those experiences are often encoded.

As the poem progresses, the tone shifts from being demanding to suggestive. This illustrates a mitigated and more nuanced relationship between the speaker and his unhealthy lifestyle, resonating with the way in which an addict relates to his or her substance of choice. The initial instruction to '[s]top slouching man' (1.4) is refashioned in the next line as '[a]void that lazy boy slouching' (1. 5). The speaker refigures the absolute term 'stop' into the merely suggestive 'avoid'. In this shift, the speaker reflects a mitigation, however slight, of the non-negotiable nature of indulgence. The insertion of the word 'lazy boy' as a noun modifier reinscribes the homeliness and intimacy that characterises the relationship between an addict and his substance of choice, denoted here as 'slouching'. Similarly, the intimacy of the suggestion that the speaker 'wave[s] goodbye' (1.6) to metaphoric unhealthy foodstuffs rearticulates a familiarity and closeness between the addict and his excesses. The poem's construction of this complex relationship reframes the later privileging of 'these fabulous goodies' over sobriety. Significantly, the only time that the first-person pronoun ' $\mathrm{I}$ ' is used in the poem is in the penultimate lines when the speaker says 'stop this shortlived challenge/And as I do every single year/Get stuck into these fabulous goodies' (11. 8-10). It is interesting and eerily tragic that the speaker's only pronominal invocation of agency and suggestion of a fully constituted self is when he ostensibly relapses. He does this by selecting his illicit desires, the specific nature of which remains simultaneously known and unsayable as indicated by the pronoun 'these'.

The urgency and difficulty of attaining sobriety is expressed when the speaker reflects that '[i]t's D-day for a beach body' (1. 2). The historically militaristic references to 'D-day' and 'beach' could gesture towards the inexorable entanglement of both destruction and possibility that characterised the Normandy landings during the Second World War. It is this confluence of loss and hope that characterises the speaker's locatedness within the liminal space of recovery. Significantly, the urgency with which the 'beach body' is identified as the epitome of healthy living is significant for the way in which it foregrounds the visibility of sobriety, suggesting an encroachment of the exteriority of the social on the individual's personal experience. The simultaneously constitutive and disruptive function of the societal gaze is a theme that also appears in 'Up, up and away!' and 'Armageddon chess' and is suggestive of the broader complexities of negotiating narrative selfhood in the discursive formation of addiction and recovery. It also suggests an intrusion in the present of an imagined future self. The unimaginable difficulty that the speaker experiences in sustaining willpower is similarly evidenced when he says '[b]e brave and eat an apple' (1. 7). The hyperbolic suggestion that bravery is necessary simply to eat fruit suggests slippages in the poem's structuring metaphor and reinscribes specificity into the poem's otherwise decontextualised depiction of willpower. 


\section{Armageddon chess}

Double seven branched light reflecting flames

These are the standards of the game

2

You have to be worthy and brave

Otherwise you ought to be ashamed

It will make you an angelic saint

Glowing with true skilful and talented master play

Or leave, you on the granite rocks in the

reflection of the glass gray

The short poem 'Armageddon chess' can be read as describing an addict who is seemingly attempting to simplify the choice between sobriety and addiction by conceptualising it as a clearly delineated binary of positive versus negative (a thematic bifurcation that recurs in both 'Up, up and away' and 'Time to get summer-ready'). The poem utilises religious imagery, which resonates closely with the significance of religious and spiritual discourses in many recovery models predicated on the Twelve Step and similar approaches. It may, however, also be possible that the utilisation of religious imagery is not necessarily linked to the discourses of recovery that are prevalent in many rehabilitation centres. The 'Armageddon' in the title already suggests a sense of finality, and the choice is imagined as life being a game that plays out against the backdrop of this eventuality. The image of the Armageddon game and its decisive effect on the speaker's sense of self and hopes for the future are embedded within good/bad and heaven/hell binaries that are carried through the poem. The attempt to demarcate the choice as an uncomplicated binary is consistently disrupted, however, by a conflation of the two sides.

The opening line combines the two sides of the binary through the use of the number 7 , which is often associated by many Christian denominations with the notion of the God figure, as well as the presence of fire, an element that is frequently connected with Satan and hell. The 'Double seven branched light' (1. 1) points to what the speaker experiences as the recurrent presence of the God figure. As the godly 'branched light' is described as 'reflecting flames', this may be read as an admission of uncertainty as to whether the light can be trusted to be purely good or evil, as flames are suggested to present both renewal and destruction.

In the confusion that the speaker experiences, the 'standards of the game' (1. 2) are laid out when he seems to address himself in the second person (1.3). Continuing the good/evil, God/Satan dichotomies, the options open to the participant in the game function in a similarly dualistic way: either the player 'must be worthy and brave' (1. 3) or conversely, and with clear finality, the player must resign to feelings of shame, and, within the metaphor of the game, failure (1. 4). ' $\mathrm{tt}^{\prime}$, the antecedent in line 5, does not grammatically seem to refer directly to lines 4 or 5 but to the act of successfully playing the game. The metaphor of the game invites the sense of an active participant being watched by spectators. As in the previous two poems, the speaker in 'Armageddon chess' thus situates himself as the subject of society's gaze. In other words, the absence of a direct reference to succeeding at the game may speak to the underlying (and thus unspoken) feeling of unattainability surrounding the possibility of sobriety, which is further enforced by the tautological description of the 'saint' as 'angelic'.

The speaker's desire to master the game is expressed in the saint-like description of what the good player appears to be in the second last line: 'Glowing with true skilful and talented master play' (1. 6). The descriptor '[g]lowing' emphasises the importance of appearance, and the sense that the controlled presentation of the exterior for the sake of the spectator is what is finally important. This is abruptly followed by the alternative to success, again in the dualistic style that structures the poem: 'Or leave, you on the granite rocks in the reflection of the glass gray [sic]' (1.7). The deliberate insertion of a comma after 'Or leave' results in a pause that, in tandem with the inversion at the end of the line ('in the glass gray'), emphasises the final image of failure, wherein the speaker's self shatters upon 'granite rocks'. What is more, the imperfect and uneven reflection offered by 'the glass gray' also points to the speaker's inability to conceptualise a singularly coherent and articulate self-image in recovery. Though a large part of the poem is typified by the constant reminder of what failure may entail, the use of seven lines reinforces the speaker's desire to master the game and end up on the side of good, even though the poem suggests an overpowering sense of confusion resulting from the broad extremes in which he has been compelled to conceptualise the game, and through that, the construction of his identity within the discourses of addiction and recovery.

\section{The lingering blackness}

Into the water with pale coloured eyes

Silence. Lurking through the black of night,

Drowning emotions in the shadow of death

A grim nightmare of cruelty and finality

The delicate corpse withered in magnificent misery

Fear, terror. And obsession to murder the flesh

A sudden delight believed to amaze a fiery heart

That thought moulded on an ancient dream

Nothing, death, the end

A corpse kept secret in the strange night

In the poem, 'The lingering blackness', the image of a force at work in the speaker's psyche could represent her experience with addiction. This force, referred to in the title as 'The lingering blackness', enters a mass of water in the first line, '[i]nto the water with pale coloured eyes' (1. 1). The idea of a submersion into a mass of water is emphasised by the typography of the poem. Using the cut-and-paste method, the poet took care to choose words of more or less the same size. These were carefully arranged in evenly spaced lines which form subtle waves, mimicking the appearance of a calm body of water. 
The diction in the first stanza creates a melancholic, if slightly indulgent tone. The force is referred to as 'blackness'. Its eyes are described as being pale coloured. Proverbially, eyes are seen as the windows to the soul and are generally perceived to be an accurate indicator of someone's mood and state of consciousness. Therefore, the eyes are often perceived to betray, for example, a drug user's illicit behaviour. The eyes are described as being 'pale coloured' (1.1), which could suggest that they betray weakness, feebleness or shock in addition to having a light hue. In the following line, the word 'silence' (1. 2) suggests a state of isolation and introspection. This idea is again underscored by the typography of the poem which allows significant spaces between the words, suggesting that each word is isolated from the other. The force is described as '[1]urking through the black of night' (1. 2). The words 'black' and 'night' add to the melancholy atmosphere created by the diction, while the word '[1]urking' suggests that the force is threatening, hidden and perhaps involved in forbidden activities. In the fourth line, the force's purpose in the water is revealed: to drown 'emotions in the shadow of death' (1. $3)$. The fact that the water is described as '[t]he shadow of death' (1. 3) suggests a dichotomy between two states: one submerged in the water, which can be presumed to be the state of inescapable intoxication and the other outside of the water, sobriety. The force lures or compels the subject into the water, or 'the shadow of death' (1. 3), which metaphorically compares the submerged, intoxicated state to a state akin to death. This can be read as an intertextual resonance to John Donne's (1993 [1633]) 'Death, be not proud' which refers to 'rest and sleep' as 'pictures' of death (1. 5). Therefore, the speaker in this particular poem also suggests that the state of intoxication is a precursor of death. This points to the inherent danger and sense of annihilation associated with substance abuse, as well as a possible escape from life.

Unlike sleep or similar states of altered consciousness, the submerged state is therefore not temporary, but also resembles death in its irrevocability. The speaker is unequivocal in representing the submerged state as undesirable as well. In the last line of the first stanza, however, there is a glorification of the state as the corpse of the emotions drowned by the force is firstly described as 'delicate' (1. 5) which implies a vulnerability as well as grace and elegance. Secondly, the corpse is withering in 'magnificent misery' (1.5). The alliteration draws attention to the apparent oxymoron. The change from undesirability to glorification begs a motivation, which is then explored in the second stanza. The pace is quickened in this stanza by the punctuation after the words '[f]ear' and 'terror' (1. 6), while the use of the word 'obsession' (1. 6) simultaneously emphasises the speaker's urgency. The phrase 'murder the flesh' (1. 6) suggests a desire to commit self-harm. The idea that the self-harming behaviour results from an uncomfortable psychological state is raised again by the juxtaposition of the words '[f]ear' and 'terror' (1. 6) with 'and obsession to murder the flesh' (1. 6), as if the state of fear directly leads to an impulse of self-destruction.
The speaker also uses the word 'murder' rather than 'suicide', suggesting an experience of dislocation from the self.

Self-destruction then also provides the speaker with a kind of escape, which is a common perspective on addiction (Clark 2011:59). The fear and terror experienced in the previous line are transformed into '[a] sudden delight' (1.7). This delight is suggested to 'amaze a fiery heart' (1. 8), which implies that its intensity surprises even those with a passionate and emotional rather than a rational and reserved disposition. The use of the word 'believe' (1. 8), however, suggests that the amazement of the 'fiery heart' (1. 8) might only be an illusion. The 'sudden delight' (1. 8) might be pursued for a reason found to be invalid or false. Thus, selfhood is cast as contingent and inescapably entangled with revisionist imaginings of the past and uneven projections of the future.

This idea is confirmed in the next line, where the belief is now referred to as a 'thought' (1.9) which is 'moulded in an ancient dream' (1. 9). If the thought is 'moulded' (1. 9) on a dream, it must therefore be a reproduction of that dream and in itself not authentic. The dream is furthermore 'ancient' which imbues it with mythical connotations, suggesting a dream which is idealised and imagined.

The betrayal of the 'sudden delight' (1. 8) is apparent in the 10th line, which describes its outcome as 'nothing, death, the end' (1. 10). These three concepts denote absence and finality - the result of which, referred to as 'a corpse' (1. 11), must be hidden in 'the strange night' (1. 11). Despite the apparent certainty of notions of nothingness and finality with which the experiences are framed, this is undermined by the unknowability of that which is 'secret' and 'strange' (1. 10). These final words of the poem therefore reinforce the setting of night-time isolation and uncertainty, sketched in the first stanza.

Therefore, the presumable state of addiction and/or drug use described in the poem is characterised by certain conditions. It contains two distinct states: one is undescribed, while the other is threatening, dark, and leads to self-destruction. The boundary between these states is transgressed on the presumption that it is associated with passion, emotion and feeling. Paradoxically, the force that lures the speaker into this state is also said to suppress or undo emotion. The promise of this state to those with a passionate disposition is also betrayed, as the state leads only to destruction and a permanent end. In this poem, the agency that has been conferred on the external force shifts back to the speaker. That being said, this agency is marked by the speaker as truncated and she remains cynical about the possibilities of recovery.

\section{Ethical consideration}

This research was undertaken as part of a community engagement project, which was approved by the College of Human Sciences Research Ethics Review Committee of the 
University of South Africa. The names of all participants have been anonymised in order to protect their identities and privacy.

\section{Conclusion}

In this study we consider some contexts and discourses surrounding addiction and find that academic and professional discourses currently provide various models and approaches to the subject of addiction, each model viewing the addict's agency in a different manner. The medical view tends to limit the addict's agency, while the psychological view regards agency as instrumental to addiction in that addiction is a result of insufficient willpower. The moralist view grants full agency to the addict in the sense that addiction is seen as a consequence of prioritising pleasure. Furthermore, addiction is sometimes used as a hyperbole or a metaphor in colloquial discourse and becomes the scapegoat on which moral society's burdens are projected. Elements of these discourses are evident throughout the four poems in this study, indicating the various extents to which these factors intersect with discursive formations of identity in the contexts of addiction and recovery.

The four poems that we analyse attempt to create binary oppositions between different perspectives, times and spaces. In 'Up, up and away!', the past, present and futures selves are regarded as separate entities. No reference is made to the past, and the future is presented as unknowable. The speaker finds herself in a liminal state, and the prospect of a new identity seems unattainable. The speaker makes a deliberate attempt to regain agency by first shifting from a position of being looked at and scrutinised, to a position in a tree house where he or she can gaze upon others.

The speaker in 'Time to get summer-ready', however, only seems to regain agency when he or she relapses. There seems to be a familiarity and closeness between the addict and his addiction while sobriety and recovery remain an unknowable and 'different' expectation. Therefore, the speaker remains suspended between the conditions of destruction and possibility, loss and hope, while caught in the exteriority of the societal gaze.

In 'Armageddon chess', a final binary between the positive ('good') and the negative ('evil') is disrupted by a conflation of the two sides. It is not certain whether the light mentioned in the first line of the poem can be trusted to be either purely good or entirely evil. The speaker's attempt to delineate two broad extremes leads only to confusion, and even tentative imaginings of success seem to remain unattainable.

The speaker in 'The lingering blackness' projects her agency onto an external force which disappears towards the end of the poem. Self-destructive behaviour serves as an escape from an uncomfortable psychological space, leading to two states: one of feeling versus one of not feeling. This state of not feeling is compared to being submerged, isolated and concealed. Although it leads to a 'sudden delight' (1. 7), the state of not feeling is also described as being dangerous. The delight that it supposedly brings is therefore suggested to be idealised and imagined. Apart from being uncomfortable, the speaker's state of feeling remains largely undescribed, begging the question of whether it would be a state of safety or of more danger.

In conclusion, the speakers in these poems attempt to map their experiences and identities onto several structuring binaries. This includes the speaker's own internal experience versus societal expectations and perceptions; as well as the speaking subject's present circumstances in the rehabilitation centre versus an imagined future outside of this insular environment. The subject's own agency in these different spheres is approached in a very tentative way and the speakers in these poems have trouble envisioning the future. These binaries therefore seem to be unsuitable for the speakers' use. However, unlike mainstream discourses and vocabularies surrounding addiction, the genre of poetry provides a platform that better accommodates ambivalence and a multiplicity of meanings, even if those meanings point to a limitation in verbal expression.

While this study attempts to trace poetry's potential to express alternative ways of mapping subjective experiences of addiction, other literary genres may, in the context of a rehabilitation centre, allow for even more varied creative responses. A genre such as drama, for example, encourages a connection to the outside world. It is simultaneously produced and received, and therefore necessitates a direct and immediate encounter with its audience (see Eversmann 2004:141). Studies that investigate the possibilities of other genres as modes of expression in circumstances similar to those of this study would contribute towards bodies of knowledge aiming to understand the nuanced ambiguities of identity construction in addiction.

In this study, the writing of poetry functions as a means of expression that counters the limitations imposed by the dominant discourses surrounding the recovery from addiction. While these discourses often tend to bifurcate addiction from recovery and health from disease, poetry as a form of expression enables these states to exist simultaneously. In doing so, it allows for ways of conceptualising addiction that are not based on metaphors of stigma and shame. As Sontag (1989:96) argues in relation to AIDS, these 'metaphors cannot be distanced just by abstaining from them. They have to be exposed, criticised, belaboured [sic], used up'. As a genre that lends itself to the articulation of seemingly irreconcilable discontinuities, poetry is able to scrutinise and reframe those binary conceptions of addiction.

\section{Acknowledgements Competing interests}

The authors declare that they have no financial or personal relationship(s) which may have inappropriately influenced them in writing this article. 


\section{Authors' contributions}

All authors contributed to the article equally.

\section{References}

Anonymous, 2015a, 'Armageddon chess', Unpublished poem, Unisa, Pretoria.

Anonymous, 2015b, 'The lingering blackness', Unpublished poem, Unisa, Pretoria.

Anonymous, 2015c, 'Time to get summer-ready', Unpublished poem, Unisa, Pretoria.

Anonymous, 2015d, 'Up, up and away', Unpublished poem, Unisa, Pretoria.

Bailey, L., 2005, 'Control and desire: The issue of identity in popular discourses of addiction', Addiction Research and Theory 13(6), 535-543. https://doi. org/10.1080/16066350500338195

Clark, M., 2011, 'Conceptualising addiction: How useful is the construct?', International Journal of Humanities and Social Science 1(13), 55-64.

Coonfield, G., 2008, 'Mapping addicted subjection', Cultural Studies 22(1), 80-113. https://doi.org/10.1080/09502380701480436

Dladla, A., 2015, 'Demystifying writing and the democratisation of the story and knowledge', Current Writing 27(2), 86-94. https://doi.org/10.1080/101392 9X.2015.1086192

Donne, J., 1993 [1633], 'Death be not proud', in M.C. Andersen, S.G. Kossick \& E. Pereira (eds.), A new university anthology of English poetry, p. 24, Oxford University Press, Oxford.
Eversmann, P., 2004., 'The experience of the theatrical event', in V.A. Cremona, P. Eversmann, H. van Maanen, W. Sauter \& J. Tulloch (eds.), Theatrical events: Eversmann, H. van Maanen, W. Sauter \& J. Tulloch (eds.),
Borders, dynamics, frames, pp. 139-174, Rodopi, Amsterdam.

Foddy, B. \& Savulescu, J., 2010, 'A liberal account of addiction', Philosophy, Psychiatry, \& Psychology 17(1), 1-22. https://doi.org/10.1353/ppp.0.0282

Hitchcock, J.L., 2005, 'Reflections on "Dusting": Poetry's educational and therapeutic capacity to convey and evoke multiple meanings', Journal of Poetry Therapy 18(4), 195-205. https://doi.org/10.1080/09670260500289053

Kleyn, L., 2012, 'Ons kyk vanself - Kreatiewe skryfkuns, konkrete poësie en 'n verset teen skrywersnorme', Literator 33(1), 1-29.

Krueger, A., 2015, 'Whose voice is it anyway? Implications of free writing', Current Writing 27(2), 103-110. https://doi.org/10.1080/1013929X.2015.1086195

Morgenstern, J. \& McCrady, B.S., 1992, 'Curative factors in alcohol and drug treatment: Behavioural and disease model perspectives', British Journal of Addiction 87, 901 912. https://doi.org/10.1111/j.1360-0443.1992.tb01985.x

Randolph, R.M., 2012, 'Substance to symbol: Towards the inclusion of great poetry in alcohol addiction recovery programs', Journal of Poetry Therapy 25(3), 165-171. https://doi.org/10.1080/08893675.2012.709717

Sontag, S., 1978, IIIness as metaphor, Farrar, Straus and Giroux, New York, NY.

Sontag, S., 1989, AIDS and its metaphors, Farrar, Straus and Giroux, New York, NY.

Springer, W., 2006, 'Poetry in therapy: A way to heal for trauma survivors and clients in recovery from addiction', Journal of Poetry Therapy 19(2), 69-81. https://doi. org/10.1080/08893670600756632

Wiens, T.K. \& Walker, L.J., 2014, 'The chronic disease concept of addiction: Helpful or harmful?', Addiction Research and Theory 23(4), 309-321. https://doi.org/10.310 9/16066359.2014.987760 